\title{
Conflict Analysis of PT Emas Mineral Murni in Nagan Raya and Central Aceh Regency
}

\author{
Dharma Kelana Putra 1,* (D) Wahyu Wiji Astuti 2, (D) and \\ Muhammad Hafidz Assalam 2 \\ ${ }^{1}$ Balai Pelestarian Nilai Budaya Aceh, 23123, Banda Aceh, Indonesia \\ 2 Department of Indonesian Literature, Faculty of Language and Art, \\ Universitas Negeri Medan, 20222, Medan, North Sumatra, Indonesia \\ * Corresponding Author: dharma.kelana@kemdikbud.go.id
}

\section{ARTICLE INFO}

\section{Publication Info:}

Literature Review

How to cite:

Putra, D. K., Astuti, W. W., E Assalam, M. H. (2020). Conflict Analysis of PT Emas Mineral Murni in Nagan Raya and Central Aceh Regency. Society, 8(2), 529545.

DOI: $10.33019 /$ society.v8i2.193

Copyright (C) 2020. Owned by Author(s), published by Society

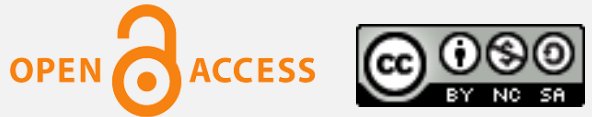

This is an open-access article.

\section{License: Attribution- NonCommercial-ShareAlike (CC BY-NC-SA)}

Received: June 14, 2020;

Accepted: August 31, 2020;

Published: December 18, 2020;

\section{ABSTRACT}

This research describes how the mining conflicts in Nagan Raya and Central Aceh Regency between the local community and PT Emas Mineral Murni (PT EMM). This research uses a descriptive qualitative method with a literature study as a data collection technique by searching literature through online news pages on the internet using the search keyword "Aceh Conflict PT EMM". Content analysis uses Occam's razor logical principle to read and interpret data to explain a complete picture of the conflict situation without involving unnecessary assumptions. This research found many stakeholders involved in the conflict aside from the local community and PT EMM. Besides, the conflict is focused not only on competition to seize natural resources but also on overlapping legal authority. Low interaction between stakeholders causes conflict to grow and develop. The conflict's final result is a resolution in the form of a petition signed by the Acting Governor. He stated that he would sue PT EMM with a guarantee of resigning from the position if he cannot realize Acehnese students' aspirations.

Copyright (C) 2020. Owned by Author(s), published by Society. This is an open-access article under the CC-BY-NC-SA license. https://doi.org/10.33019/society.v8i2.193 


\section{Introduction}

Indonesia is long known as a country rich in natural resources, which consist of renewable natural resources and non-renewable natural resources. From one of the state-owned companies engaged in the mineral mining sector alone, the potential for natural wealth (mineral reserves) is worth IDR 15,000 trillion (CNBC Indonesia, 2018). No wonder many parties want to manage this natural wealth to get the maximum benefit for them, and conflict in this context occurs as an excess of natural wealth struggle (Apriyanto \& Harini, 2012; Irwandi \& Chotim, 2017).

In mining conflicts, business actors or corporations often experience disputes with local communities (Prayogo, 2010; Juniah et al., 2013; De Angelis, 2004; Hidayat, 2020). The conflicts occur because business actors' interests tend to intersect with local communities' interests (Akpalu \& Parks, 2007; Fringka, 2016). When the community knows that there is natural wealth in their area with high economic potential, many parties want to own and manage it. However, that enormous wealth should not be owned by a handful of people as stated in article 33 paragraph 3 of the 1945 Constitution, "The land, waters, and natural resources within shall be under the powers of the State and shall be used to the greatest benefit of the people" (Republik Indonesia, 2002).

Conflict in the mining sector is undoubtedly not a new case in Indonesia because this conflict has been going on for a long time in various areas and has become a social disease (social symptom) in society (HukumOnline, 2015). Recently, mining conflicts have recurred again, to be precise, in Nagan Raya Regency and Central Aceh Regency, Aceh Province, Indonesia. Initially, the conflict only occurred between the corporation (PT Emas Mineral Murni) and the local community, expressed in the form of refusal actions in several locations. The conflict grew and turned into a dispute over the granting of Mining Business License between the Aceh Government and the Central Government.

Previous research has shown that in conflicts that occur in the mining sector, local communities are directly affected by the activities carried out by the company. Starting from the loss of livelihoods, the decline in the quality of public health, the emergence of community diseases in the environment where they live, to the impact of prolonged environmental damage (Down \& Stock, 1977; Fisher et al., 2009; Hilson, 2010; Maconachie, 2011; Zhang et al., 2012; Apriyanto \& Harini, 2012; Juniah et al., 2013; Aminah, 2017; Listiyani, 2017; Hidayat, 2020). Previous studies link the similarity of typology where the state is more pro corporations than local communities. Often, in reality, it is not fulfilling the promises when the mining company will establish.

This situation has taught many parties that the mining business brings more negative impacts than positive benefits to the area's communities. Moreover, in this case, the community saw that the natural wealth contained in Aceh's land belonged to the Acehnese people, so they could not give up any "outsiders" take it for their interests without considering the sustainability of the local community's life even though with the authorization of Central Government (Sinarpidie.co, 2019). They understand that gold and other minerals exploitation were leaving an area of damaged and abandoned mining areas (WALHI Aceh, 2019). Even if there are benefits for the Acehnese people during mining operations, this amount is small, often referred to as Corporate Social Responsibility. The rest is actually "outsiders" who enjoy a lot.

This condition has previously been felt by Aceh's people when PT Arun is still operating in Lhokseumawe (TRIBUNnews.com, 2014). At that time, PT Arun's existence brought modernization into Aceh and made Aceh one of the "Petrodollar" areas in Sumatra. However, at the end, when PT Arun stopped operating, what remains are only memories. This experience

Copyright ( $(2020$. Owned by Author(s), published by Society. This is an open-access article under the CC-BY-NC-SA license.

https://doi.org/10.33019/society.v8i2.193

530 
has undoubtedly taught the Acehnese people to be skeptical and reject mining companies whose existence is deemed not to have significantly contributed to Aceh's development. At its peak, students held an action by occupying the Aceh Governor's office from 9 to 11 April, 2019.

Conflicts in the mining sector, if not correctly addressed, will have negative impacts on a relatively wide scale. Also, the slow handling of conflict will cause various impacts on people's lives, such as the destruction or breakdown of group unity, property destruction, and life loss. Therefore, the conflict needs to be exposed to discover what happened behind the mining conflicts in Nagan Raya and Aceh Tengah Regency. On that basis, this research describes how the mining conflicts in Nagan Raya and Central Aceh Regency between the local community and PT Emas Mineral Murni (PT EMM). With the hope that this research will become a foundation for other research, which will find a suitable mechanism so that the conflict does not escalate and cause a more significant impact.

\section{Literature Review}

Conflict is one form of social interaction in society. In simple terms, Lacey $(2003, \mathrm{p} .17)$ says that conflict defines as a fight, clash, resistance, contestation, contradiction, and the opinion that has a purpose, mental strife, or a struggle between conflicting interests. Conflict is dynamic, not rigid, and can be managed and utilized to benefit specific groups (Susan, 2009; Wirawan, 2010). This nature makes the conflict very vulnerable to influences from various aspects, both between the parties to the conflict and other structures or parties outside them. Fisher et al. (2001) argues that the issues of attitudes, behavior, and conflict situations divide into three types, including:

1) Latent conflict; describes a situation where an existing conflict is below the surface with the potential to emerge.

2) Open conflict; describes a real conflict situation that has very visible and deep-rooted and requires various actions to address the root cause.

3) Surface conflict; describes a where an existing conflict is visible but shallow or with no roots and arises only because of a misunderstanding.

Article 5 of Law Number 7 of 2012 concerning Handling of Social Conflict (Republik Indonesia, 2012) states that conflict can originate from:

1) problems related to politics, economy, and socio-culture;

2) clashes between religious communities and/or between religious believers, between tribe groups, and between ethnic groups;

3) disputes over the village, regency/city, and/or provincial boundaries;

4) natural resource disputes between communities and/or between communities and business actors; or

5) unequal distribution of natural resources in society.

Conflicts that arise due to natural resource disputes between communities and/or between communities and business actors in the mining sectors are often arising and relatively complicated. Because it is not only friction between two parties in a conflict and but also involves many parties with various interests over the contested resources (Akpalu \& Parks, 2007; Hilson, 2010; Apriyanto \& Harini, 2012; Satriani, 2015; Aminah, 2017; Irwandi \& Chotim, 2017; Hidayat, 2020).

Business actors (corporations) usually won in conflicts in mining sectors on local communities. They have enormous resources, both financial and experienced human resources (Down \& Stock, 1977; De Angelis, 2004; Yunita \& Hendrastomo, 2018; Hidayat, 2020). 
Community groups that succeed in winning conflicts with business actors are rare unless they receive support from various parties (Fringka, 2016; Irwandi \& Chotim, 2018; Pratama, 2018). Based on a win-win solution, the consensus often occurs because people have no other choice (Soares, 2004; Usboko, 2016; Putri \& Adi, 2020).

Related to this, De Angelis (2004) argues that corporations have a great tendency to cooperate with Regional Governments in mining conflicts. This collaboration resulted in a practice of enclosure or fencing, which can interpret a strategy to naturally distance the local community from the various resources around it by borrowing the state's hands. Corporations tend to find it easier to control natural resources when they keep the community away from access to natural resources around them.

Table 1. State-led Analysis of Enclosure Practices Framework

\begin{tabular}{|l|l|}
\hline \multicolumn{1}{|c|}{ Type of Enclosure } & \multicolumn{1}{c|}{ Mode of Enclosure } \\
\hline Land and resources & $\begin{array}{l}\text { 1. Create land policies and determine tax rates } \\
\text { (Mexico); }\end{array}$ \\
& $\begin{array}{l}\text { 2. Externalities (polluting soil and water to keep } \\
\text { people away) (Nigeria and India); }\end{array}$ \\
\hline Urban planning & $\begin{array}{l}\text { 3. Privatization of water (Bolivia); } \\
\text { 4. Neoliberal war. }\end{array}$ \\
\hline Social interests & $\begin{array}{l}\text { 1. City design (infrastructure development); } \\
\text { 2. Road construction. }\end{array}$ \\
\hline Knowledge and life & $\begin{array}{l}\text { 1. Budget cuts for social costs; } \\
\text { 2. Withholding rights. }\end{array}$ \\
\hline
\end{tabular}

Source: De Angelis (2004)

Collaboration between government and corporations had produced many types and modes of the enclosure to keep local people away from their resources. Prayogo (2010) reveals that the anatomy of conflicts between corporations and local communities often could not be separated from the government role as a third party, especially in terms of the significance of conflict, the level of conflict dynamics, and the significance of conflict resolution. On which side the government takes sides usually will determine which party will win the conflict (Susan, 2009; Wirawan, 2010; De Angelis, 2004; Syah, 2015; Irwandi \& Chotim, 2017; Munawwaroh et al., 2018).

Furthermore, Susan as cited in Putra (2010), argues that conflicts usually arise at different scales, ranging from interpersonal conflicts, intergroup conflicts, conflicts between groups and the state (vertical conflict), and conflicts between countries (interstate conflict). The bigger the scale of the conflict that occurs, the more complex the conflict will be to analyze. In this regard, Putra (2010) argues that in analyzing conflict, there are at least several factors that need to be considered, including:

1) Stakeholders, namely parties in conflict or interested in the conflict's occurrence, include individuals, groups, and third parties (mediators, free riders, and others). 
2) Sources, including physical differences, differences in interests, differences in treatment, differences in identity, disappointment, limited resources, differences in language, disconnection of communication, differences in perceptions, and others.

3) Interaction, namely, social relationships between individuals or groups, can cause conflict or occur during the conflict.

4) Process, namely how the conflict started and how it lasted until now. The conflict process also includes the extent to which conflict or potential conflict will occur, described as conflict escalation and de-escalation.

5) Expression, namely in what form the conflict is shown, includes speech (verbal), writing, gestures, physical contact, and others.

6) Result, including how the final result or temporary development of a conflict is or has occurred, such as win-win, win-lose, and lose-lose conditions.

\section{Research Methodology}

This research uses descriptive qualitative methods, which Bogdan \& Taylor as cited in Moleong (2007, p. 3), said as a procedure that produces descriptive data flexibly and variedly. This method is more suitable for seeing a problem more precisely and in-depth.

This research is not field research, so there is no data from direct interviews and observations. The type of data used in this research is secondary data, collecting from books, journals, and online news pages on the internet using the search keyword "Aceh Conflict PT EMM".

The data collection process was carried out for one week, starting from 3 May to 9 May, 2019. The collected data were reviewed and then edited, and then put in chronological form. Information obtained from one online media must be verified by checking and comparing other online media or credible pages containing this information, such as companies, organizations, governments, and others, to ensure the data's validity (William et al., 1988, p. 110).

The content analysis technique is used as an analysis knife to reveal the meaning of data in the text. This technique can parse text objectively and systematically and be applied to produce more simple descriptions (Krippendorf, 1993; Suprayogo \& Tobroni, 2001). A common thread can be drawn from this series of processes to obtain a complete picture of the conflict that has occurred until it finally becomes a conclusion.

\section{Results and Discussion}

\subsection{Stakeholders}

The mining conflicts in the PT EMM case in Nagan Raya Regency and Aceh Tengah Regency were not as simple as assumed. The parties involved in the conflict were the local community and PT EMM and involved many stakeholders. Based on the analysis of secondary data collected from several online media, it can conclude that the parties in conflict or have an interest in the occurrence of conflict in this case include:

1) PT Emas Mineral Murni (PT EMM) is a company engaged in the mining sector and Asiamet Resources Limited subsidiary. Asiamet Resources Limited is an Australia-owned company. PT Emas Mineral Murni obtained a Mining Business License from the Central Government through the Indonesian Investment Coordinating Board to manage mining production operation in the concession area in Nagan Raya Regency and Central Aceh Regency. Based on ownership, $80 \%$ of PT EMM is currently owned by Beutong Resources PTE Ltd (BRPL), while PT Media Mining Resources, an Indonesian-owned company, owns the other 20\%. BRPL itself was initially a Singapore-owned private company, 50\% of which was owned by 
Tigers Copper Singapore No. 1, PTE Ltd. Due to specific issues, Asiamet Resources Limited has acquired Tiger Copper No. 1 PTE Ltd (Asiamet Resources, 2019). This shift in ownership occurred in 2017, which indirectly shifted its scheme from domestic investment to foreign investment on December 19, 2017, which then shifted the Regional Government's authority to the Central Government (Kontan.co.id, 2019).

2) The community comprises people living around the PT EMM concession area in four villages in Beutong Ateuh Banggalang Sub-District, Nagan Raya Regency, and directly affected by PT EMM's mining production operation. Some of them then formed a forum for struggle named Kombatan (Koalisi Masyarakat Bersatu Tolak Tambang or Coalition of Unified Communities to Refuse Mining).

3) Students are a coalition of several student organizations from various universities in Aceh, which then unite in Barisan Pemuda Aceh (BPA or Aceh Youth Front) action in Banda Aceh and the Student Action for the Beutong Ateuh Banggalang Generation (AM-GBAB or Aksi Mahasiswa untuk Generasi Beutong Ateuh Banggalang) in West Aceh.

4) The Aceh government, in this context, can grant licenses to mining companies with domestic investment scheme operating in the Aceh Province. The authority based on Law Number 11 of 2006 concerning the Aceh Government (Republik Indonesia, 2006), Government Regulation Number 3 of 2015 concerning Government Authority which is National in Aceh (Presiden Republik Indonesia, 2015), Aceh Qanun Number 15 of 2013 concerning Management of Mineral and Coal Mining (Gubernur Aceh, 2013), and Qanun Aceh Number 7 of 2016 concerning Aceh Forestry (Gubernur Aceh, 2016).

5) The Central Government, through the Indonesian Investment Coordinating Board, in this context, has the authority to grant Mining Business License for Production Operation to mining companies with foreign investment scheme. In this context, the Central Government considered overstepping the Aceh Government in decision-making and licensing.

6) The Indonesian Forum for the Environment (WALHI) of Aceh is a non-governmental organization that focuses on environmental sustainability issues, including assistance and advocacy for local communities.

\subsection{Sources}

Conflicts between mining companies and communities around mining operating areas are no longer a new case in Indonesia. During the 2018 period, the Indonesian National Police recorded 240 cases of legal violations in the mining sector, some of which were related to legislation such as overlapping licenses, procedural errors in granting licenses, and others (CNN Indonesia, 2018).

In the case between PT EMM and the Acehnese community, the conflict source stems from the difference in perceptions of the authority to grant Mining Business License between the Aceh Government and the Central Government through the Indonesian Investment Coordinating Board. The Central Government considers that granting Mining Business Licenses to companies with foreign investment scheme is under the Indonesian Investment Coordinating Board's authority. Meanwhile, the people of Aceh consider that the Mining Business License grant by the Investment Coordinating Board violates the Aceh Government's various privileges.

Moreover, PT EMM allegedly does not have a Borrowing to Use Forest Area Licenses from the Ministry of Environment and Forestry (WALHI Aceh, 2018a). Furthermore, based on the results of the map overlay conducted by WALHI of Aceh on the PT EMM Environmental Impact Analysis Report, the 10,000-hectare Mining Business License for Production Operation 
area is located in Beutong Sub-district, covering an area of 21.71 hectares, and Beutong Ateuh Banggalang Sub-district covering an area of 6,259.93 hectares, in Nagan Raya Regency. Then in Peugasing Sub-district with an area of 2,084.81 hectares and Cilala Sub-district with an area of 1,259.74 hectares, both located in Central Aceh Regency. Meanwhile, the concession area has the status of Protection Forest covering an area of 5,981.87 hectares (Protected Forest in the Leuser Ecosystem (Kawasan Ekosistem Leuser or KEL) covering 918.25 hectares), while the Other Use Area (Areal Penggunaan Lain or APL) covers 3,914.33 hectares (APL in KEL 343.22 hectares) (Merdeka.com, 2019).

Besides differences in perceptions, there are differences in interests between conflicting parties. PT EMM has an interest in maintaining a concession area of 10,000 hectares, which is estimated to contain mineral resources in the form of copper of 1.5 million tons, gold 79.8 thousand ounces, and silver around 941.5 thousand ounces in Nagan Raya Regency and Central Aceh Regency (Kontan.co.id, 2019). Meanwhile, the community is interested in managing forest and land resources, which have been their livelihood in the region (Liputan6.com, 2018). Besides, there are also graves of charismatic scholars highly respected by the local community in the area.

Meanwhile, WALHI has an interest in the preservation of natural resources in PT EMM's concession area. Apart from this area, according to Aceh's spatial plans, it is an area prone to ecological disasters that must be sterile from any exploitation activities. The area is the Leuser Ecosystem Area (KEL), which is protected. Natural exploitation by mining companies will also leave large holes in the ground and natural damage for a long time (Merdeka.com, 2019).

\subsection{Interaction}

In this case, the interaction related to social relations between stakeholders leads to realistic conflicts between PT EMM and the community. There are several things to pay attention to, the first is communication, and the second is about interest "who does what, to get what".

Based on the news data collected from online media, there was no reasonable communication effort from PT EMM to the community regarding their activities. For the company, this may be a simple matter, but it has a significant impact. Even though the company has obtained licenses from the Central Government, it cannot neglect the affected community's existence as a social licensor. Without good communication, the company will appear arbitrarily towards the communities' interests around its operational areas. Of course, this situation will also cause negative reactions from the community, which results in prolonged conflict.

Then, what is interesting is how the relationship that exists between PT EMM and the government, both at the central and regional levels, especially in licensing. Even though the local community rejected the activities carried out by PT EMM through various actions, the Nagan Raya Regency Government was still steadfast in providing exploration licenses, temporary suspension licenses, and environmental licenses. This situation shows a good relationship between PT EMM and the Regency Government as the licensor, and there is a bad relationship between PT EMM and the Regency Government with the affected community.

The issuance of Aceh Governor Instruction Number 11/INSTR/2014 concerning Moratorium on Mining Business License for Metal Minerals and Coal indicates a bad relationship between PT EMM with the Aceh Government, which they think could result in problems in the future. However, PT EMM carried out a maneuver that made the licensing authority process shift from the Aceh Government to the Central Government by changing the investment scheme from domestic investment to foreign investment in 2017. In the end, this

Copyright ( $(2020$. Owned by Author(s), published by Society. This is an open-access article under the CC-BY-NC-SA license.

https://doi.org/10.33019/society.v8i2.193

535 
process caused a public reaction that forced the Aceh Government to dispute over authority against the Central Government (Indonesian Investment Coordinating Board) related to the authority of the Aceh government in managing natural resources. The Central Government considered having violated Aceh's privileges in managing mineral resources and mining materials.

Based on the regulations, granting licenses to PT EMM had to be considered by the Governor of Aceh, but this did not happen. There are significant problems related to the interaction between the Central Government, Aceh Government, and PT EMM in granting Mining Business License for Production Operation, which raises allegations from the community, that there is a conflict of interest and potential legal violations in the process (TRIBUNnews.com, 2018).

\subsection{Process}

The conflict between PT EMM and the local community did not appear recently but had been since the beginning when PT EMM conducted exploration in 2006. Until the end of 2018, more than nine actions were protesting PT EMM's activities, which took place at a different place and time. However, this series of actions is deemed not to have received a good response from the Nagan Raya Regency Government and the Aceh Government (Kompas.com, 2019a). On April 11, 2019, Aceh Acting Governor gave a firm answer regarding the policy's direction and his side.

On the one hand, the community and students were furious because PT EMM was considered a powerful bargaining position to obtain various licenses. Moreover, the actions so far seem to have no influence. This situation is interpreted as a form of arbitrariness by the Central Government towards the people and corporate oppression against communities around the mining management area, thus triggering more concrete actions.

On the other hand, PT EMM's struggle to obtain licenses is a very long and complicated negotiation process. Not only at the Nagan Raya Regency Government level but also at the Provincial and Central Government levels. PT EMM has successfully secured various licenses related to the operations they will carry out at the regency level, ranging from exploration licenses to environmental licenses. While at the Central Government level, PT EMM also obtained various licenses, both exploration licenses from the Ministry of Energy and Mineral Resources and investment licenses from the Indonesian Investment Coordinating Board.

During the period 2005 to 2014, PT EMM has done many things, from obtaining exploration licenses and research on Environmental Impact Analysis. However, all this turned into uncertainty when the Governor of Aceh issued a moratorium in October 2014. Moreover, the moratorium was issued several months after PT EMM obtaining the Temporary Termination Approval Letter from the Nagan Raya Regent in June 2014. Of course, it is not easy to give up all that hard work, thus prompting them to look for other ways to legally strengthen their position.

In 2017, 80\% of PT EMM's shares acquired by a Singaporean company, Beutong Resources PTE Ltd (BRPL). 50\% of the shares of BRPL owned by Tigers Cooper Singapore No. 1 PTE Ltd. Later, an Australian company, Asiamet Resources Limited, acquire all of Tigers Cooper Singapore No. 1 PTE Ltd shares. The shift in shared ownership scheme from domestic investment to foreign investment resulted in the shift of licensing authority from the Regional Government to the Central Government (AceHTrend.com, 2018). Not long after that, the Central Government issued Mining Business License for Production Operation to PT EMM through the Indonesian Investment Coordinating Board with Decree Number 
66/I/IUP/PMA/2017 on December 19, 2017 (Tirto.id, 2019).

This licensing basis then puts PT EMM's operations outside the authority of the Aceh Government. Moreover, PT EMM claims that they follow the prevailing laws and regulations so that there is no reason for other parties to stop their activities. The strategy adopted by PT EMM is similar to the case of forest land grabbing in Lingkar Tambang Village, Lede District, Taliabu Regency, North Maluku Province. In this case, when the conflict with the local community began to experience a gestational phase, the company changes the share ownership scheme from domestic investment to foreign investment to gain strong support from the Central Government for licensing issues (Hidayat, 2020).

\subsection{Expression}

Since the beginning, PT EMM's activities have experienced rejection from the community, even since the mine's opening was still a topic of discussion in 2006. The community understands that opening a mine area will affect their lives and livelihoods. The community wrote the letter to the Regent of Nagan Raya and the Governor of Aceh on March 28, 2013, to express their demand for rejecting the existence of PT EMM in their area. The letter was signed before by Geuchik (village head) and community leaders from four villages, consisting of Babah Suak Village, Kuta Tengoh, Blang Puuk, and Blang Meurandeh (Merdeka.com, 2019).

The rejection attitude expression aims to make the leaders realized that opening the mine area would not prosper the local community but only enriched the capital owners by extracting Aceh's natural resources and leaving lasting environmental damage. Besides, this rejection attitude is a warning that the activities carried out by PT EMM will potentially create quite extensive and prolonged conflicts.

Apart from correspondence, conflicts were also expressed by WALHI Aceh and the community by taking legal remedies through the State Administrative Court (WALHI Aceh, 2018b). They filed a lawsuit against the Indonesian Investment Coordinating Board for granting Mining Business License for Production Operation to PT EMM. The license grant has several irregularities, including shifts in share ownership of PT EMM, shifts in scheme from domestic investment to foreign investment, and authority shifts from Regional Government to the Central Government. There is no socialization in placing boundary marks, concession areas that do not follow the Environmental Impact Analysis documents.

WALHI of Aceh and the community realize that the licenses held make PT EMM have management rights protected by law. No one can intervene in their activities while they are operating according to applicable regulations. On that basis, they also filed a lawsuit against the government to revoke the permit granted by presenting evidence and bringing several villagers as representatives to testify at the trial on April 11, 2019 (BBC News Indonesia, 2019).

In this conflict, the public and students also expressed rejection through peaceful actions and demonstrations. So far, the actions have occurred up to nine times since 2013 (Kompas.com, 2019b). Peaceful actions and demonstrations carried out by communities from 4 affected villages, consisting of Babah Suak Village, Kuta Tengoh, Blang Puuk, and Blang Meurandeh in Beutong Ateuh Banggalang Sub-district along with WALHI of Aceh and students from various universities in Aceh. For example, signing the petition on a white cloth and installing it on a steel frame bridge, the access road from Beutong Ateuh Banggala to Central Aceh, and holds a grand dhikr event with the theme "Joint Prayer Against PT EMM's Mining" (Mongabay, 2018).

The public and students also held demonstrations to exert pressure on policymakers to be more pro-community interests. On October 15, 2018, students who were members of the Student Action for the Beutong Ateuh Banggalang Generation (Aksi Mahasiswa untuk Generasi

Copyright ( $(2020$. Owned by Author(s), published by Society. This is an open-access article under the CC-BY-NC-SA license. https://doi.org/10.33019/society.v8i2.193 
Beutong Ateuh Banggalang or AM-GBAB) staged demonstrations in front of the People's Representative Council Building of West Aceh Regency in Meulaboh to demand the revocation of PT EMM's production and operation licenses.

Then, thousands of students from various universities in Aceh, associated with Barisan Pemuda Aceh (BPA or Aceh Youth Front) take action by occupying the Aceh Governor's office from April 9 to 11, 2019. They were overseeing the process of a lawsuit submitted to the Indonesian Investment Coordinating Board regarding licenses granting for PT EMM at the Jakarta State Administrative Court. Besides, they also demanded the Acting Governor of Aceh to revoke PT EMM's operation licenses.

On April 9, 2019, the first day of demonstrations ended with a clash that resulted in injuries from both security and students and damage to office building facilities (Kompas.com, 2019a). While the second day of demonstrations also ended with a riot. The students destroyed the fence and removed the signboard for the Aceh governor's office. Besides, they also made "graves" from paving blocks around the site. On the third day, the action culminated when students received information that the Jakarta State Administrative Court rejected their lawsuit. To calm the situation, the Acting Governor of Aceh then met the demonstrators. The Acting Governor of Aceh agreed to sign a petition containing the Aceh Government's commitment to revoke the PT EMM license and resolve the dispute (Mongabay, 2019). The contents of the petition include:

"First, the Acting Governor of Aceh is ready to carry out a lawsuit through the Aceh
Government as a form of defending the specialty of Aceh and defending the people of
Aceh. Second, the Acting Governor of Aceh is ready to recommend revoking PT Emas
Mineral Murni (PT EMM). Third, condemn the Central Government's actions that
do not respect the specificity of Aceh that resulted from the peace points between Aceh
and Indonesia. Fourth, the Acting Governor of Aceh ready to open up and criticize the
mastermind behind the establishment of PT EMM in Aceh".

Upon learning the rejection of their lawsuit, in a separate location, the Beutong Ateuh Banggalang Sub-district people then went to the PT EMM camp complex. They carried out forced evictions of workers and stopped all activities in the gold mining area. After being pressured, PT EMM's public relations official, Dwiyanto, was finally willing to sign a statement with a stamp, stating that they would leave Aceh (Mongabay, 2019). PT EMM's public relations official, Dwiyanto, states that he and the workers experienced intimidation and signed the statement because they were under duress (ANTARA News Aceh, 2019).

\subsection{Result}

Until now, the conflict between PT EMM and the Acehnese people is still ongoing administratively. Physical tension has not happened again, but in the ongoing PTUN legal process to find a win-win solution. Until now, PT EMM has ceased all its activities in the mine area. They dismantled the camp and evacuated all workers according to the statement letter signed by the Public Relations of PT EMM on April 11, 2019 (DetikNews, 2019a). The community and students have stopped the action as a commitment to the petition. On the other hand, the Aceh Government has formed a Team for the Acceleration of Dispute Resolution for the Granting of Mining Business License to PT Emas Mineral Mumi (PT EMM).

The initial effort made by the Aceh Government was by sending letter number 545/6320 on April 18, 2019, to the Minister of Energy and Mineral Resources, which contained the revocation 
of the Governor of Nanggroe Aceh Darussalam Recommendation Number 545/12161 dated June 8, 2006. The Aceh Government also sending letter number 545/6321 on April 18, 2019, to the Indonesian Investment Coordinating Board to review or re-evaluate the Indonesian Investment Coordinating Board' Decree Number 66/1/IUP/PMA/2017, dated December 19, 2017, regarding the Granting of Mining Business License for Production Operation to PT EMM (DetikNews, 2019b). The hope is that there will be no overlapping in the issuance of licenses between the Aceh Government and the Central Government in the future.

\subsection{The Common Thread of Mining Conflict in Aceh}

Conflicts between mining companies and local communities are not new to Indonesia and show the same phenomenon. Susan (2009) categorizes conflicts between mining companies and local communities as intergroup conflicts. Meanwhile, according to the conception put forward by Fisher et al. (2001), conflicts that occur in the mining sector are open conflicts and require complex handling in its resolution.

In various literature stated that this conflict usually ends in three scenarios, consisting of 1) the company wins, the community loses, 2) the community wins, the company loses, and 3) the community and the company establish good relations and reach a consensus based on the principle of a win-win solution (Down \& Stock, 1977; De Angelis, 2004; Soares, 2004; Susan, 2009; Usboko, 2016; Yunita \& Hendrastomo, 2018; Hidayat, 2020; Putri \& Adi, 2020). As a result of the conflict between the community and PT EMM, the community managed to win against the mining company and force them to withdraw for an indefinite period.

Based on the analytical framework developed by De Angelis (2004), the conflict between the community and PT EMM was not challenging to reveal because it was still in the type of enclosure of land and natural resources. Meanwhile, the mode of enclosure tends to lead to externalities by borrowing the state's hands to keep people away from natural resources in their environment, including using loopholes in the prevailing laws and regulations.

In mining sectors, there are many loopholes in Indonesia's laws and regulations, and these gaps tend to be exploited by certain parties in achieving their goals (Pratama, 2009; Sarmadi, 2012; Putra, 2016; Buli et al., 2018). This perspective sees that PT EMM was exploiting loopholes in overlapping regulations between the Central Government and the Aceh Government, so PT EMM's investment scheme maneuvers appear legitimate in law. The public is aware that the investment scheme's change occurred not long after the Governor issued the instruction for the Moratorium on Mining Business License for Metal Minerals and Coal in 2014. In simple terms, the company is still the same even though the investment scheme has shifted from domestic investment to foreign investment (Suhesti, 2018).

Unlike in other regions in Indonesia, the people of Aceh, in this conflict, had a high bargaining position. There are several factors, consisting of 1) Aceh was a region with special autonomy which gave the Aceh Government greater authority to regulate resource management; 2) The people of Aceh have a long experience of conflict, from the colonial period to the post-independence era. The conflicts ended with the MoU's signing in Helsinki between Aceh and the Central Government several years ago. Thus, conflict with mining companies is no longer a big problem because the people of Aceh have already fought against the state.

After the conflict's escalation, there has been no definitive resolution of the dispute over authority between the Central Government and the Aceh Government regarding the licenses for PT EMM in Nagan Raya and Central Aceh Districts. On the one hand, the community hopes that PT EMM's operating permit is revoked by the Central Government, while on the other hand, PT EMM hopes to resume their pending activities. Of course, this is a relatively intense

Copyright ( $(2020$. Owned by Author(s), published by Society. This is an open-access article under the CC-BY-NC-SA license. 
process of tug of interest. In simple terms, the company has spent many resources to carry out mining activities. In contrast, the community rejected this company and prohibited from operating by the Aceh Government. Not only because of legality, but the problem is that the community does not want mining companies to exploit natural resources on their land.

This research has many shortcomings, which allow for more intensive and in-depth followup studies. The shortcomings in this research are that the data analyzed comes from online news pages, so that the formed construction has not been able to describe the whole conflict from its various aspects. Moreover, because this research is not a field study, actual data were not obtained from the location of the conflict between PT EMM and the local community, either in the form of documentation, observation notes, or information from the first source (conflicting parties). Hopefully, this study's weaknesses can pave the way for further research, with more complete supporting data and more in-depth analysis from one aspect to another of the conflicts that have occurred.

\section{Conclusion}

Mining conflicts in the PT EMM case in Nagan Raya and Aceh Tengah districts were not as simple as previously assumed. In this case, there are many parties (stakeholders) involved. Then, conflict sources are also fighting over natural resources and the intertwined issue of legal authority. Low interaction between stakeholders causes conflict to grow and develop, like a fire in the husk, which many do not suspect when expressed. Meanwhile, the final result obtained is a dispute over the authority to grant Mining Business License between the Aceh Government and the Central Government at the State Administrative Court.

Mining conflicts that occur in Aceh and other areas should make the government introspect. The natural resource wealth must be appropriately utilized for the people's benefit, as mandated by the 1945 Constitution in Article 33 Paragraph 3. Not only for the interests of foreign corporations or even a handful of unscrupulous officials who take advantage of power to get economic benefits from cooperation results. In the end, the government or officials' partisanship tested through the policies taken to resolve conflicts, whether they continue to side with the corporation or the community.

This research has many shortcomings, which allow for more intensive and in-depth followup studies. The shortcomings in this research are that the data analyzed comes from online news pages, so that the formed construction has not been able to describe the whole conflict from its various aspects. Moreover, because this research is not a field study, actual data were not obtained from the location of the conflict between PT EMM and the local community, either in the form of documentation, observation notes, or information from the first source (conflicting parties). Hopefully, this study's weaknesses can pave the way for further research, with more complete supporting data and more in-depth analysis from one aspect to another of the conflicts that have occurred.

\section{Acknowledgment}

The authors are grateful to express gratitude to all of those who have had the pleasure to work during this research conducted.

\section{Declaration of Conflicting Interests}

The authors have declared no potential conflicts of interest concerning the research, authorship, and/or publication of this article. 


\section{References}

AceHTrend.com. (2018, November 2018). Ramai-ramai Tolak PT. EMM. Retrieved from: https:/ / www.acehtrend.com/2018/11/18/ramai-ramai-tolak-pt-emm/

Akpalu, W., \& Parks, P. J. (2007). Natural resource use conflict: gold mining in tropical rainforest in Ghana. Environment and Development Economics, 55-72. Retrieved from from http:/ / www.jstor.org/stable/44379330

Aminah, A. (2017). Tambang Rakyat Rentan Konflik (Studi Kasus Pertambangan Emas Rakyat Di Gunong Ujeun Kabupaten Aceh Jaya). Jurnal Public Policy, 3(2), 183-192. https://doi.org/10.35308/jpp.v3i2.123

ANTARA News Aceh. (2019, April 11). Humas PT EMM mengaku diintimidasi massa dan dipaksa teken petisi. Retrieved from: https:/ / aceh.antaranews.com/berita/71279/humas-pt-emm-mengaku-diintimidasimassa-dan-dipaksa-teken-petisi

Apriyanto, D., \& Harini, R. (2012). Dampak Kegiatan Pertambangan Batubara Terhadap Kondisi Sosialekonomi Masyarakat Di Kelurahan Loa Ipuh Darat, Tenggarong, Kutai Kartanegara. Jurnal Bumi Indonesia, 1(3), 289-298. Retrieved from http://lib.geo.ugm.ac.id/ojs/index.php/jbi/article/view/96

Asiamet Resources. (2019, November 14). Beutong Copper Gold. Retrieved from https:/ / asiametresources.com/our_project/beutong-copper-gold/

BBC News Indonesia. (2019, April 12). Tambang emas di Aceh: Aktivis dan masyarakat akan terus tolak rencana produksi PT EMM. Retrieved from: https://www.bbc.com/indonesia/indonesia-47891913

Buli, W., Bakri, S., \& Febryano, I. G. (2018). Kelembagaan Pertambangan Batubara di Hutan Rakyat. Jurnal Sylva Lestari, 6(3), 81-90. http:/ /dx.doi.org/10.23960/jsl3681-90

CNBC Indonesia. (2018, May 21). RI Punya Kekayaan Tambang Rp $15.000 \mathrm{~T}$ yang Belum Tergali. Retrieved from https://www.cnbcindonesia.com/news/20180521040045-415765/ri-punya-kekayaan-tambang-rp-15000-t-yang-belum-tergali

CNN Indonesia. (2018, February 22). Polri Catat 240 Kasus Hukum di Sektor Pertambangan. Retrieved from: https://www.cnnindonesia.com/ekonomi/20180222172759-85278120/polri-catat-240-kasus-hukum-di-sektor-pertambangan

De Angelis, M. (2004). Separating the doing and the deed: Capital and the continuous character of enclosures. Historical Materialism, 12(2), 57-87. Retrieved from https:/ / doi.org/10.1163/1569206041551609

DetikNews. (2019a, April 11). PT. EMM Keluar dari Aceh dan Kamp Dibongkar dalam 24 Jam. Retrieved from: https://news.detik.com/berita/d-4506641/pt-emm-kami-keluar-dariaceh-dan-kamp-dibongkar-dalam-24-jam

DetikNews. (2019b, April 22). Pemprov Aceh Cabut Rekomendasi Izin PT. EMM. Retrieved from: https://news.detik.com/berita/d-4520302/pemprov-aceh-cabut-rekomendasiizin-pt-emm

Down, C. G. \& Stock, J. (1977). Environmental Impact of Mining. New York, United States: John Wiley and Sons.

Fisher, E., Mwaipopo, R., Mutagwaba, W., Nyange, D., \& Yaron, G. (2009). "The ladder that sends us to wealth": Artisanal mining and poverty reduction in Tanzania. Resources Policy, 34(1-2), 32-38. https:/ / doi.org/10.1016/j.resourpol.2008.05.003

Fisher, S., Ludin, J., Williams, S., Abdi, D. I., Smith, R., \& Williams, S. (2001). Mengelola konflik: keterampilan dan strategi untuk bertindak. Jakarta, Indonesia: British Council.

Copyright (C 2020. Owned by Author(s), published by Society. This is an open-access article under the CC-BY-NC-SA license. 
Fringka, Y. (2016). Resistensi Berbasis Adat: Perlawanan Masyarakat Nagari III Koto, Tanah Datar, Sumatera Barat, Terhadap Rencana Tambang Bukit Batubasi. MASYARAKAT: Jurnal Sosiologi, 205-231. https:// doi.org/10.7454/mjs.v21i2.4670

Gubernur Aceh. (2013, December 13). Qanun Aceh Nomor 15 Tahun 2013 Tentang Pengelolaan Pertambangan Mineral dan Batubara. Lembaran Aceh Tahun 2013 Nomor 15. Retrieved from https://ppid.acehprov.go.id/inpub/?keyword=Qanun Aceh Nomor 15 Tahun 2013 Pengelolaan Pertambangan Minerba

Gubernur Aceh. (2016, November 10). Qanun Aceh Nomor 7 Tahun 2016 Tentang Kehutanan Aceh. Lembaran Aceh Tahun 2016 Nomor 10. Retrieved from https://peraturan.bpk.go.id/Home/Details/34504/qanun-prov-nad-no-7-tahun-2016

Hidayat, R. (2020). Politik Teritorial dan Perampasan Tanah-Hutan di Desa Lingkar Tambang Bijih Besi, Kecamatan Lede, Kabupaten Taliabu, Provinsi Maluku Utara. Emik: Jurnal Ilmu-Ilmu Sosial, 3(1), 1-16. https:/ / doi.org/10.46918/emik.v3i1.491

Hilson, G. M. (2010). Enclaves of Wealth and Hinterlands of Discontent. Accra, Ghana: Third World Network-Africa.

HukumOnline. (2015, October 16). Konflik di Wilayah Tambang Telah Jadi Penyakit Sosial. Retrieved from https://www.hukumonline.com/berita/baca/1t561f67b0661b6/konflikdi-wilayah-tambang-telah-jadi-penyakit-sosial/

Irwandi, I., \& Chotim, E. R. (2017). Analisis Konflik Antara Masyarakat, Pemerintah Dan Swasta. JISPO: Jurnal Ilmu Sosial dan Ilmu Politik, 7(2), 24-42. https://doi.org/10.15575/jp.v7i2.2414

Juniah, R., Dalimi, R., Suparmoko, M., \& Moersidik, S. S. (2013). Dampak Pertambangan Batubara terhadap Kesehatan Masyarakat Sekitar Pertambangan Batubara (Kajian Jasa Lingkungan Sebagai Penyerap Karbon). Jurnal Ekologi Kesehatan, 12 (2), 128-138. Retrieved from https://www.neliti.com/publications/80463/dampak-pertambangan-batubaraterhadap-kesehatan-masyarakat-sekitar-pertambangan

Kompas.com (2019a, April 9). Tolak Izin Tambang di Aceh, Demo Mahasiswa Ricuh di Kantor Gubernur. Retrieved from: https:/ / regional.kompas.com/read/2019/04/09/22375571/tolak-izin-tambang-di-acehdemo-mahasiswa-ricuh-di-kantor-gubernur

Kompas.com. (2019b, April 11). 5 Fakta Demo Mahasiswa di Aceh Tolak Izin Tambang, Ricuh hingga 9 Kali Tak Ada Tanggapan Plt Gubernur Halaman 2 - Kompas.com. Retrieved from https://regional.kompas.com/read/2019/04/11/14523361/5-fakta-demomahasiswa-di-aceh-tolak-izin-tambang-ricuh-hingga-9-kali-tak?page=2

Kontan.co.id. (2019, April 12). ESDM: Soal PT EMM minta dicabut, nanti dulu. Retrieved from https://industri.kontan.co.id/news/esdm-soal-pt-emm-minta-dicabut-nanti-dulu

Krippendorff, K. (1993). Analisis Isi: Pengantar dan Teori Metodologi. Jakarta, Indonesia: Rajawali Pers.

Lacey, H. (2003). How to Resolve Conflict in The Workplace. Jakarta, Indonesia: PT Gramedia Pustaka Utama.

Liputan6.com. (2018, September 29). Gejolak Tambang Emas di Daerah Sakral Aceh. Retrieved from https://www.liputan6.com/regional/read/3653595/gejolak-tambang-emas-didaerah-sakral-aceh

Listiyani, N. (2017). Dampak Pertambangan Terhadap Lingkungan Hidup di Kalimantan Selatan dan Implikasinya Bagi Hak-hak Warga Negara. Al-Adl: Jurnal Hukum, 9(1), 67-86. Retrieved from https://ojs.uniska-bjm.ac.id/index.php/aldli/article/view/803 
Maconachie, R. (2011). Re-agrarianising livelihoods in post-conflict Sierra Leone? Mineral wealth and rural change in artisanal and small-scale mining communities. Journal of International Development, 23(8), 1054-1067. https://doi.org/10.1002/jid.1831

Merdeka.com. (2019, April 12). Geger Emas di Perut Bumi Aceh. Retrieved from https:/ / www.merdeka.com/peristiwa/geger-emas-di-perut-bumi-aceh.html

Moleong, L. J. (2007). Metodologi Penelitian Kualitatif: Bandung, Indonesia: PT Remaja Rosdakarya.

Mongabay. (2018, September 11). Tegas! Masyarakat Beutong Tolak Perusahaan Tambang Emas. Retrieved from: https://www.mongabay.co.id/2018/09/11/tegas-masyarakatbeutong-tolak-perusahaan-tambang-emas/

Mongabay (2019, April 14). Janji Plt Gubernur Aceh pada Masyarakat: Akan Gugat Izin Tambang PT. EMM. Retrieved from: https://www.mongabay.co.id/2019/04/14/janjiplt-gubernur-aceh-pada-masyarakat-akan-gugat-izin-tambang-pt-emm/

Munawwaroh, T., Zuhdi, S., \& Wahyudi, B. (2018). Peran Pemerintah Daerah Dalam Penanganan Konflik Tambang Emas di Kabupaten Trenggalek, Provinsi Jawa Timur. Damai dan Resolusi Konflik, 4(1), 45-72. Retrieved from http:/ /139.255.245.7/index.php/DRK/article/view/205

Prayogo, D. (2010). Anatomi konflik antara korporasi dan komunitas lokal pada industri geotermal di Jawa Barat. Makara, Sosial Humaniora, 14(1), 25-34. Retrieved from http:/ / www.ijil.ui.ac.id/index.php/humanities/article/view/568

Pratama, M. I. C. (2009). Kepastian Hukum Dalam Product Sharing Contract (Thesis). Universitas Islam Indonesia. Retrieved from https://fh.uii.ac.id/wp-content/uploads/2013/01/FHUII-KEPASTIAN-HUKUM-DALAM.pdf

Pratama, S. (2018). Dimensi Ekonomi Politik Dalam Konflik Tata Kelola Pertambangan (Studi Kasus Surat Keputusan Gubernur Bangka Belitung Tentang Penghentian Sementara Operasional Pertambangan Laut PT Timah, Tbk Tahun 2016). JWP (Jurnal Wacana Politik), 3(1), 40-53. https:/ / doi.org/10.24198/jwp.v3i1.16084

Putra, D. A. (2016). Eksistensi Sistem Hukum Perizinan Kegiatan Pertambangan Dalam Otonomi Daerah Sebagai Salah Satu Instrumen Hukum Hak-Hak Masyarakat. Legality: Jurnal Ilmiah Hukum, 24(1), 12-26. https:/ / doi.org/10.22219/jihl.v24i1.4264

Putra, D. K. (2010). Potensi Konflik Komunitas Jawa Muslim Terhadap Etnis Berbeda Dan Penganut Agama Lain Di Kota Medan (Thesis). Universitas Sumatera Utara. Retrieved from http:/ / repository.usu.ac.id/handle/123456789/22509

Putri, M. S. P., \& Adi, A. P. (2020). The Myth of Economic Growth in Tumpang Pitu Gold Mine in Banyuwangi East Java. Jurnal Partisipatoris, 2(1), 51-57. https://doi.org/10.22219/jp.v2i1.11746

Sarmadi, A. S. (2012). Penerapan hukum berbasis hukum progresif pada pertambangan batu bara di Kalimantan Selatan. Masalah-Masalah Hukum, 41(1), 8-19. Retrieved from https:/ / ejournal.undip.ac.id/index.php/mmh/article/view/4155

Satriani, S. (2015). Hubungan negara-warga dan demokrasi lokal: Studi konflik tambang di Bima. Jurnal Penelitian Politik, 12(2), 33-49. Retrieved from http:/ / ejournal.politik.lipi.go.id/index.php/jpp/article/view/540

Sinarpidie.co. (2019, April 12). Warga Beutong Ateuh Kawal Kepergian PT EMM dari Lokasi Tambang. Retrieved from https://sinarpidie.co/news/warga-beutong-ateuh-kawalkepergian-pt-emm-dari-lokasi-tambang/index.html 
Soares, A. J. (2004). The Impact of Corporate Strategy on Community Dynamics: A Case Study of the Freeport Mining Company in West Papua, Indonesia. International Journal on Minority and Group Rights, 11(1-2), 115-142. https:/ / doi.org/10.1163/1571811041631263

Suhesti, I. (2018). Pembentukan Perusahaan Cangkang Oleh Penanam Modal Asing Di Indonesia (Thesis). Universitas Airlangga. Retrieved http:/ / repository.unair.ac.id/id/eprint/70007

Suprayogo, I., \& Tobroni. (2001). Metodologi Penelitian Sosial-Agama. Bandung, Indonesia: PT Remaja Rosdakarya.

Susan, N. (2009). Sosiologi Konflik dan Isu-Isu Konflik Kontemporer. Jakarta, Indonesia: PT Kencana Prenada Media Group.

Syah, R. F. (2015). Menambang Emas di Tanah Using: Kekuasaan dan Manajemen Konflik Pada Tambang Emas Tumpang Pitu di Kabupaten Banyuwangi (Master's dissertation). Universitas

Gadjah Mada. Retrieved from http:/ / etd.repository.ugm.ac.id/penelitian/detail/81273

Presiden Republik Indonesia. (2015, February 12). Peraturan Pemerintah Republik Indonesia

Nomor 3 Tahun 2015 Tentang Kewenangan Pemerintah Yang Bersifat Nasional Di Aceh.

Lembaran Negara Republik Indonesia Tahun 2015 Nomor 28. Retrieved from https://www.bphn.go.id/data/documents/15pp003.pdf

Republik Indonesia. (2002, August 10). Undang-Undang Dasar Negara Republik Indonesia Tahun 1945. Retrieved from https://peraturan.go.id/common/dokumen/lainlain/1945/UUD1945PerubahanKeempat.pdf

Republik Indonesia. (2006, August 1). Undang-Undang Republik Indonesia Nomor 11 Tahun 2006 Tentang Pemerintahan Aceh. Lembaran Negara Republik Indonesia Tahun 2006 Nomor $62 . \quad$ Retrieved from http://www.dpr.go.id/dokjdih/document/uu/UU_2006_11.pdf

Republik Indonesia. (2012, May 12). Undang-Undang Republik Indonesia Nomor 7 Tahun 2012 Tentang Penanganan Konflik Sosial. Lembaran Negara Republik Indonesia Tahun 2012 Nomor $\quad 116 . \quad$ Retrieved from http://www.dpr.go.id/dokjdih/document/uu/UU_2012_7.pdf

Tirto.id (2019, April 12). Gejolak di Aceh: Mahasiswa dan Masyarakat Menolak Tambang Emas. Retrieved from: https://tirto.id/gejolak-di-aceh-mahasiswa-masyarakat-menolaktambang-emas-dlXF

TRIBUNnews.com. (2014, September 30). Mau Apa Aceh Setelah PT Arun Gulung Lapak? Retrieved from https://aceh.tribunnews.com/2014/09/30/mau-apa-aceh-setelah-ptarun-gulung-lapak

TRIBUNnews.com. (2018, September 21). PT EMM Beri Penjelasan Terkait Kasus Penolakan Tambang Emas. Retrieved from https://aceh.tribunnews.com/2018/09/21/pt-emmberi-penjelasan-terkait-kasus-penolakan-tambang-emas

Usboko, I. (2016). Role Players Analysis dalam Konflik Pengelolaan Sumber Daya Alam (Studi Kasus Konflik Pertambangan Mangan Di Kabupaten Timor Tengah Selatan, Provinsi Nusa Tenggara Timur Tahun 2010-2011). Politika: Jurnal Ilmu Politik, 7(1), 16-36. https:/ / ejournal.undip.ac.id/index.php/politika/article/view/12561

WALHI Aceh. (2018a, December 19). Press Release: PT.EMM Tidak Memiliki IPPKH. Retrieved from: https:/ / walhiaceh.or.id/press-release-pt-emm-tidak-miliki-ippkh/

WALHI Aceh. (2018b, May 9). Press Release: Walhi Aceh Tolak PT. EMM. Retrieved from: https:/ / walhiaceh.or.id/press-release-walhi-aceh-tolak-pt-emm/ 
WALHI Aceh. (2019, April 4). WALHI Ajukan Kesimpulan Para Penggugat pada Sidang Gugatan Izin PT. EMM. Retrieved from https://walhiaceh.or.id/press-release-walhiajukan-kesimpulan-para-penggugat-pada-sidang-gugatan-izin-pt-emm/

Wirawan. (2010). Konflik dan Manajemen Konflik: Teori, Aplikasi, dan Penelitian. Jakarta, Indonesia: Salemba Humanika.

Yunita, C. E., \& Hendrastomo, G. (2018). Konflik Tambang Emas Tumpang Pitu, Desa Sumber Agung, Pesanggaran, Banyuwangi, Jawa Timur. E-Societas, 7(3), 1-16. http://journal.student.uny.ac.id/ojs/index.php/societas/article/view/12530

William, F., Rice, R. E., \& Rogers, E. M. (1988). Research Methods and the New Media. New York, United States: Simon and Schuster.

Zhang, X., Yang, L., Li, Y., Li, H., Wang, W., \& Ye, B. (2012). Impacts of lead/zinc mining and smelting on the environment and human health in China. Environmental monitoring and assessment, 184(4), 2261-2273. https:// doi.org/10.1007/s10661-011-2115-6

\section{About the Authors}

1. Dharma Kelana Putra, obtained his Magister degree in Anthropology from Universitas Gadjah Mada, Indonesia, in 2020. The author is a General Functional Civil Servants at Balai Pelestarian Nilai Budaya Aceh, Banda Aceh, Indonesia.

E-Mail: $\underline{\text { dharma.kelana@kemdikbud.go.id }}$

2. Wahyu Wiji Astuti, obtained her Magister degree in Literature from Universitas Gadjah Mada, Indonesia, in 2014. The author is an Assistant Professor at the Department of Indonesian Literature, Faculty of Language and Art, Universitas Negeri Medan, Indonesia.

E-Mail: wahyu_wiji@yahoo.com

3. Muhammad Hafidz Assalam, obtained his Magister degree in Literature from Universitas Gadjah Mada, Indonesia, in 2015. The author is an Assistant Professor at the Department of Indonesian Literature, Faculty of Language and Art, Universitas Negeri Medan, Indonesia. E-Mail: hafidzassalamku@gmail.com 